\title{
Editorials \\ Does socio-economic status influence \\ the use of mental health services?
}

\author{
Editoriali
}

Può lo stato socio-economico influenzare

l'utilizzazione dei servizi di salute mentale?

\section{MICHELE TANSELLA, Editor}

The relationship between socio-economic status (SES) and use of mental health services has been subjected to research for a long time. The early observations showed a concentration of people with mental disorders in socioeconomically disadvantaged areas and this stimulated further inquiries to understand if this was due to social selection or to social causation. In other words, does the place make the people or do the people make the place? In the last few years we have observed a significant increase in interest on this topic, by both researchers and administrators, as well as by mental health professionals and service users. This is due to a series of factors, including the need to use more rationally limited resources, and the emergence of issues such as accessibility to care, appropriateness of service provision, and equity in health care provision. The contribution of health geography to the refinements of methods to explore these relationships has been particularly relevant. However, this is a topic for multidisciplinary research, and the roles of social psychiatry and environmental psychology are also crucial.

This is the reason why we decided to tackle this theme in the present issue of Epidemiologia e Psichiatria Sociale, inviting three Editorials by scientists with a different scientific background. The first Editorial is by Marjan Drukker and her Colleagues at the Department of Psychiatry and Neuropsychology of the University of Maastricht. They have completed in recent years highly significant studies on this issue. After a review of the literature they concluded that, after controlling for individual SES, there is evidence for an association between neighbourhood SES and both objective and subjective mental health status in adults. The association is even stronger in young children.

The second Editorial is written by Sarah Curtis, an outstanding health geographer, now Professor of Health and Risk at Durham University in UK. She concentrates
Per lungo tempo sono state condotte ricerche sulla relazione tra stato socio-economico (SSE) ed utilizzazione dei servizi di salute mentale. Le prime osservazioni dimostrarono una concentrazione di persone con disturbi mentali nelle aree più svantaggiate da un punto di vista socio-economico e quei risultati stimolarono ulteriori ricerche, nel tentativo di capire se ciò fosse dovuto ad una selezione sociale $o$ ad un effetto causale da parte di fattori sociali. In altre parole, di capire se fosse l'ambiente ad agire sulle persone o le persone sull'ambiente. Negli ultimi anni abbiamo assistito ad un significativo aumento dell'interesse per questo filone di indagini, sia da parte di ricercatori sia da parte di amministratori, di operatori psichiatrici, ed anche di utenti dei servizi. Ciò è dovuto ad una serie di fattori, tra i quali la necessità di una più razionale utilizzazione delle limitate risorse disponibili, l'emergere di una crescente attenzione per questioni come l'accessibilità ai servizi e l'appropriatezza e l'equità delle risposte sanitarie. Particolarmente rilevante è stato poi il contributo della geografia sanitaria nella messa a punto di metodi per esplorare la relazione tra uso dei servizi e SSE. Si tratta in realtà di un filone di indagine multidisciplinare, al quale danno un contributo essenziale anche la psichiatria sociale e la psicologia ambientale.

Per questo motivo abbiamo deciso di affrontare questo tema, in questo numero di Epidemiologia e Psichiatria Sociale, invitando ricercatori di diversa formazione a scrivere tre Editoriali. Il primo è di Marjan Drukker e dei suoi Colleghi del Dipartimento di Psichiatria e Neuropsicologia dell'Università di Maastricht. Questo gruppo, negli ultimi anni, ha completato studi assai significativi in questo campo. Dopo una revisione della letteratura essi concludono che, anche se si controlla la variabilità individuale nello SSE, ci sono evidenze che dimostrano una associazione significativa tra SSE del quartiere nel quale si vive e misure obiettive e soggettive di benessere o di sof- 


\section{Tansella}

on three aspects: the influence upon service use of spatial organisation of services and of the proximity to services for different populations; the role of increasingly sophisticated ecological modelling strategies to understand the association between socio-economic attributes of the population and patterns of service use; the importance of qualitative research for improving our comprehension of the influence of non-clinical attributes of service provision on well-being and on the mental health of service users.

The third Editorial, by Francesco Amaddeo (from the Department of Medicine and Public Health of the University of Verona) and Julia Jones (from the Department of Mental Health and Learning Disabilities of City University in London), focuses on the influence of the definition of SES on the results of research, and summaries present knowledge about the relationship between SES and use of mental health services. Finally it stresses the need to fully understand how service use by individuals is influenced by their personal SES as well as by the SES of the place in which they live. This is in order to provide greater equality in access to mental health care.

There is no doubt that the long history of research on geographical variations in the use of psychiatric facilities (mental hospitals in the past, community-based mental health services in our days), will continue in the future.

\section{REFERENCES}

Amaddeo F. \& Jones J. (2007). What is the impact of socio-economic inequalities on the use of mental health services? Epidemiologia $e$ Psichiatria Sociale 16, 16-19.

Curtis S. (2007). Socio-economic status and geographies of psychiatric inpatient service use; places, provision, power and well-being. Epidemiologia e Psichiatria Sociale 16, 10-15.

Drukker M., Gunther N. \& van Os J. (2007). Disentangling associations between poverty and various levels of aggregation and mental health Epidemiologia e Psichiatria Sociale 16, 3-9. ferenza psichica. Ciò negli adulti, ma l'associazione è anche maggiore nei bambini.

Il secondo Editoriale è stato scritto da Sarah Curtis, una geografa della salute di grande valore, attualmente Professor of Health and Risk all'Università di Durham, in Inghilterra. Ella ha concentrato la sua attenzione su tre ordini di fattori: l'influenza sull'uso dei servizi sanitari da parte dell'organizzazione nello spazio dei servizi stessi ed il peso della distanza tra essi ed i luoghi dove la gente vive; il ruolo delle strategie di ricerca di modelling, oggi sempre più sofisticate, strategie che servono appunto a studiare le associazioni tra caratteristiche socio-culturali della popolazione e pattern di uso dei servizi; ed infine l'importanza assunta dalle ricerche qualitative per migliorare la nostra comprensione sul ruolo esercitato da caratteristiche non cliniche dei servizi stessi, sul benessere e sulla salute mentale degli utenti.

Il terzo Editoriale, scritto da Francesco Amaddeo (del Dipartimento di Medicina e Sanità Pubblica dell'Università di Verona) e da Julia Jones (del Department of Mental Health and Learning Disabilities della City University di Londra) si occupa dell'influenza della definizione di SSE, utilizzata dai diversi ricercatori, sui risultati della ricerca stessa e riassume i dati più recenti sulle relazioni tra SSE ed uso dei servizi di salute mentale. In questo Editoriale essi sottolineano infine la necessità di capire in quale misura l'utilizzazione dei servizi è influenzata dallo Stato socio-economico delle persone e da quello che caratterizza il luogo nel quale esse vivono. Ciò allo scopo di aumentare l'equità nell'accesso ai servizi di salute mentale.

Non c'è dubbio che la lunga storia della ricerca sull'influenza di fattori geografici sull'uso dei servizi di salute mentale (sui ricoveri in ospedale psichiatrico in passato, sull'uso dei servizi territoriali di comunità nei nostri giorni) continuerà in futuro. 